\title{
A long-term slow slip event from 1996 to 1997 in the Kii Channel, Japan
}

\author{
Akio Kobayashi
}

\begin{abstract}
We present a long-term slow slip event from 1996 to 1997 in the Kii Channel along the Nankai Trough in southwestern Japan that has not been reported previously. The long-term slow slip event had a moment magnitude Mw 6.7 and a duration of 1 to 1.5 years. The magnitude of the event was smaller than those of the Tokai (Mw 7.1) and the Bungo Channel (Mw 7.0 to 7.1) events along the Nankai Trough. The slip was located slightly shallower than the depth of the low-frequency earthquakes around the Kii Channel. Long-term slow slips have been identified in various regions along the Nankai Trough, except in the Kii Peninsula. Unveiling the history of long-term slow slips is expected to contribute to an understanding of plate boundary characteristics as well as to the prediction of large earthquakes along the Nankai Trough.
\end{abstract}

Keywords: Long-term slow slip; Nankai Trough; Kii Channel

\section{Background}

Various types of slow slip events (SSEs) have been reported along subduction plate boundaries. These events tend to exhibit large variations in duration, magnitude, and recurrence behavior (Schwartz and Rokosky 2007). Along the Nankai Trough of Japan, Hirose et al. (1999) detected a SSE with a duration of 1 year in the Bungo Channel region. Additionally, Ozawa et al. (2002) described a SSE in the Tokai region that continued for about 5 years (Suito and Ozawa 2009). In Cascadia, Dragert et al. (2001) documented a SSE that lasted for a period of several weeks. Furthermore, Obara et al. (2004) reported SSEs in the Shikoku area of Japan that lasted for several days and were accompanied by non-volcanic deep lowfrequency tremors, which are referred to as episodic tremor and slip (ETS) (Rogers and Dragert 2003). SSEs have also been reported in Mexico (Lowry et al. 2001), southern Alaska (Freymueller et al. 2002), New Zealand (Douglas et al. 2005), and Costa Rica (Protti et al. 2004).

In the Nankai Trough, SSEs with durations of several days are called short-term SSEs, and SSEs with durations of several months or years are called long-term SSEs (Obara 2011). The ETS phenomena consist of tremor episodes, deep very-low-frequency earthquakes, and short-

Correspondence: akobayas@mri-jma.go.jp

Meteorological Research Institute, 1-1 Nagamine, Tsukuba, Ibaraki 305-0052, Japan term SSEs in southwestern Japan (Obara 2011). The slip area for long-term SSEs lies between the slip area of ETS events and the source region of large earthquakes (Obara 2011). Hirose et al. (2010) discussed slow earthquakes including ETS events, long-term SSEs, and shallow verylow-frequency earthquakes in the Nankai Trough and highlighted the importance of monitoring slow earthquakes as proxies for the stress modulation process. SSEs perturb the surrounding stress field and may either increase or relieve stress on a fault, thereby bringing it closer to or farther from earthquake failure, respectively (Schwartz and Rokosky 2007).

Deep low-frequency tremors are distributed in a beltlike zone for $600 \mathrm{~km}$ along the Nankai Trough (Obara 2011); this is the area where the Philippine Sea plate is subducting beneath the Eurasian plate (Figure 1). The Japan Meteorological Agency has estimated source locations of the tremors as low-frequency earthquakes in their seismic catalog (Katsumata and Kamaya 2003). Long-term SSEs have been observed in the Bungo Channel and Tokai region of this plate boundary using Global Positioning System (GPS) data. Small long-term SSEs have also been reported in western Shikoku (Kobayashi 2010) and in Hyuga-nada (Yarai and Ozawa 2013). However, it is not yet clear whether long-term SSEs occur in other segments. Specifically, it is not known whether such events have not been observed because their

\section{包 Springer}




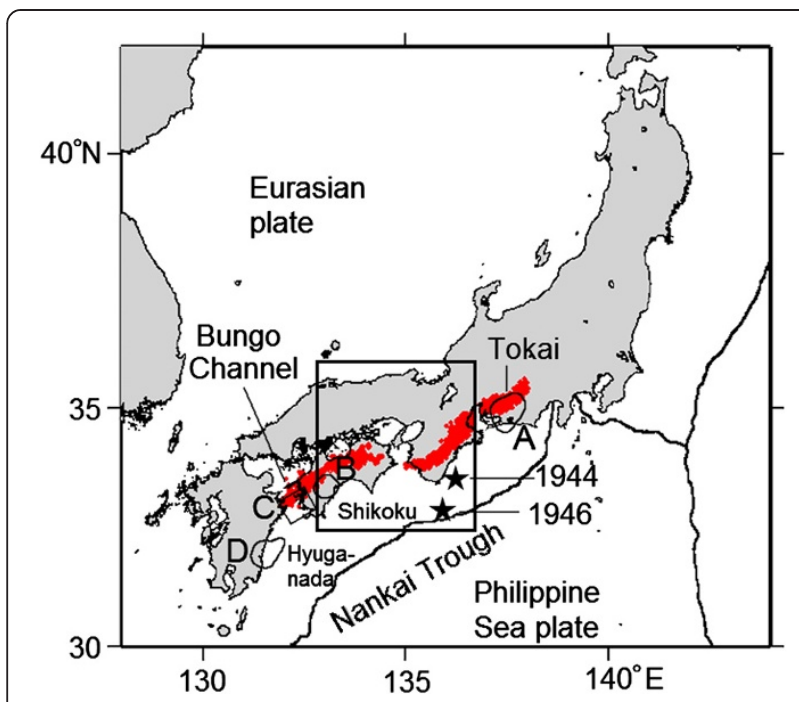

Figure 1 Regional tectonic setting and location of the study area. Solid lines indicate plate boundaries. The rectangle is the region shown in Figure 2. Red dots indicate the epicenters of low-frequency earthquakes along the Nankai Trough from January 2006 to December 2010. Stars indicate the epicenters of the 1944 Tonankai and the 1946 Nankai earthquakes. Labels A to D show locations of long-term slow slip events (SSEs) along the Nankai Trough observed by GPS. A: Tokai (Suito and Ozawa 2009). B: western Shikoku (Kobayashi 2010). C: Bungo Channel (Hirose et al. 2010). D: Hyuga-nada (Yarai and Ozawa 2013).

magnitude is small or because their recurrence interval is long. In this study, we report a newly revealed longterm SSE in the Kii Channel that was discovered through an investigation of GPS daily coordinate data.

\section{Methods \\ GPS data}

The dense continuous GPS network in Japan, called GEONET, is operated by the Geospatial Information Authority of Japan (Miyazaki et al. 1997). Since the start of the GEONET operation, there have been several changes in the routine analysis strategy (Sagiya 2004). The analysis strategy of the current so-called F3 is described in detail by Nakagawa et al. (2009). The GPS data dating back to March 1996 were re-analyzed to obtain daily coordinates through use of the uniform F3 strategy. Before March 1996, 110 GPS stations were installed in the southern Kanto and Tokai areas from 1993 to 1994, and 100 GPS stations were deployed to cover the whole of Japan in 1994 (Hatanaka et al. 2003). Hatanaka et al. (2004) re-analyzed GPS data to obtain daily coordinates for these 220 stations in conformance with the older socalled F2 strategy (Hatanaka et al. 2003).

\section{GPS daily coordinate data after March 1996}

We used daily coordinates of the GEONET F3 solution first. The strategy of GEONET F3 (Nakagawa et al. 2009) is briefly summarized as follows. The GPS data are analyzed with Bernese GPS software version 5.0 using the final ephemerides of the International Global Navigation Satellite Systems Service (IGS). The site coordinates of the GEONET stations are compared with those in the International Terrestrial Reference Frame (ITRF) 2005 (IGS05) by tightly constraining coordinates of IGS global sites to the a priori values of the ITRF2005. The strategy includes the estimation of atmospheric delay gradients.

Displacements derived from the GPS data include those from steady crustal deformation due to subduction of the Philippine Sea plate as well as those caused by episodic events such as long-term SSEs. The events that have influenced the crustal deformation around the Kii Channel after 1996 are as follows: (1) the 2000 western Tottori earthquake ( $M$ 7.3) on October 6, 2000; (2) the 2001 Geiyo earthquake (M 6.7) on March 24, 2001; (3) the 2004 off the Kii Peninsula earthquakes ( $M 7.1$ and 7.4) on September 5, 2004; (4) the 2011 off the Pacific coast of Tohoku earthquake ( $M$ 9.0) on March 11, 2011; and (5) long-term SSEs in the Bungo Channel during 1996 to 1997, 2003, and 2009 to 2010. In addition, postseismic displacements were widely observed after the 2004 off the Kii Peninsula earthquakes (Suito and Ozawa 2009) and the 2011 Tohoku earthquake (Ozawa et al. 2011). We estimated the steady deformation rate at each GPS station for 3 years from October 1997 to September 2000, avoiding periods of these events. Annual and semiannual terms are often seen in GPS coordinates (Mao et al. 1999), and they are not fully eliminated (Nakagawa et al. 2009). Therefore, we avoided their influence by using the difference of the coordinates in the same month among years. Then, we removed the estimated steady deformation rate from the data for the entire period. We also subtracted offsets due to antenna replacements by using an offset dataset [http://mekira. gsi.go.jp/JAPANESE/corrf3o.dat].

Displacements were derived from the difference in the mean coordinates of the 2-month periods at the start and the end of the assigned period. Standard deviations of the daily coordinates were calculated from the detrended data for the period from October 1997 to September 2000. Standard deviations of the displacements were evaluated by dividing the standard deviation of the daily data by $\sqrt{2 / n}$, where $n$ is the number of days in the 2-month period and $\sqrt{2}$ comes from the displacement which is the difference between two coordinates (Murakami and Ozawa 2004). Standard deviations of horizontal and vertical displacements were 2 to $3 \mathrm{~mm}$ and 4 to $6 \mathrm{~mm}$, respectively.

The results around the Kii Channel for the 2 years starting from March 1996 (Figure 2) show unsteady displacement of southwestern Shikoku caused by a longterm SSE around the Bungo Channel from 1996 to 1997 


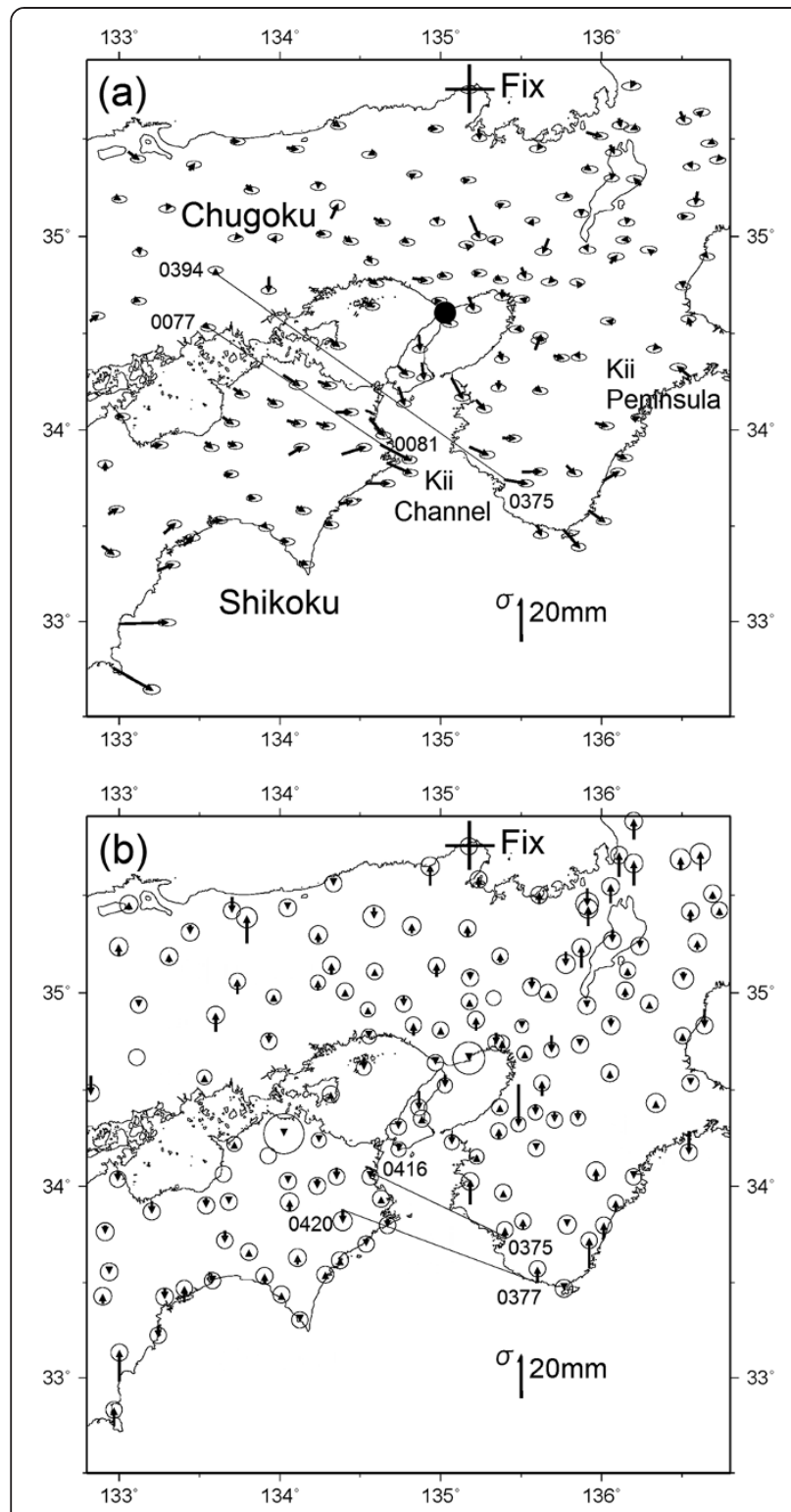

Figure 2 Detrended displacements for the period between March-April 1996 and March-April 1998. (a) Horizontal displacements. (b) Vertical displacements. The solid circle is the epicenter of the 1995 Hyogo-ken Nanbu (Kobe) earthquake. Ellipses indicate standard deviation errors. Displacement of the fix point has been subtracted from each point. Pairs of stations joined by lines correspond to the time series shown in Figure 3.

(Hirose et al. 1999). Horizontal displacements in the Chugoku district and northern Kii Peninsula were small, meaning that the observation points in these areas showed steady movements during the 2 years. Unsteady eastward or southeastward displacements of about $1 \mathrm{~cm}$, which exceeded the standard deviation, were apparent around the Kii Channel. Changes in the baseline length between various stations in the Chugoku district and around the Kii Channel (see examples in Figure 3a) were recognized between 1996 and 1997. Relative height changes of about $1 \mathrm{~cm}$ between these stations (Figure $3 \mathrm{~b}$ ) occurred over the same period, although the signal-to-noise ratio was small.

The Hyogo-ken Nanbu (Kobe) earthquake ( $M$ 7.3) occurred near the Kii Channel in January 1995. Nakano and Hirahara (1997) reported that postseismic deformation reached $20 \mathrm{~mm}$, as was indicated by GPS observations immediately after the earthquake, and they estimated that the relaxation time constant was about 50 days. We therefore assumed that the amount of change in January 1996, 1 year later, was negligible.

\section{GPS daily coordinate data before March 1996}

Because the displacement change was initiated before March 1996, we used daily coordinates of the GEONET F2 solution (Hatanaka et al. 2004). These data were analyzed with Bernese GPS software version 4.2 using IGS final ephemerides and earth rotation parameters based on the ITRF2000 (IGS00). This strategy does not include the estimation of atmospheric delay gradients. The

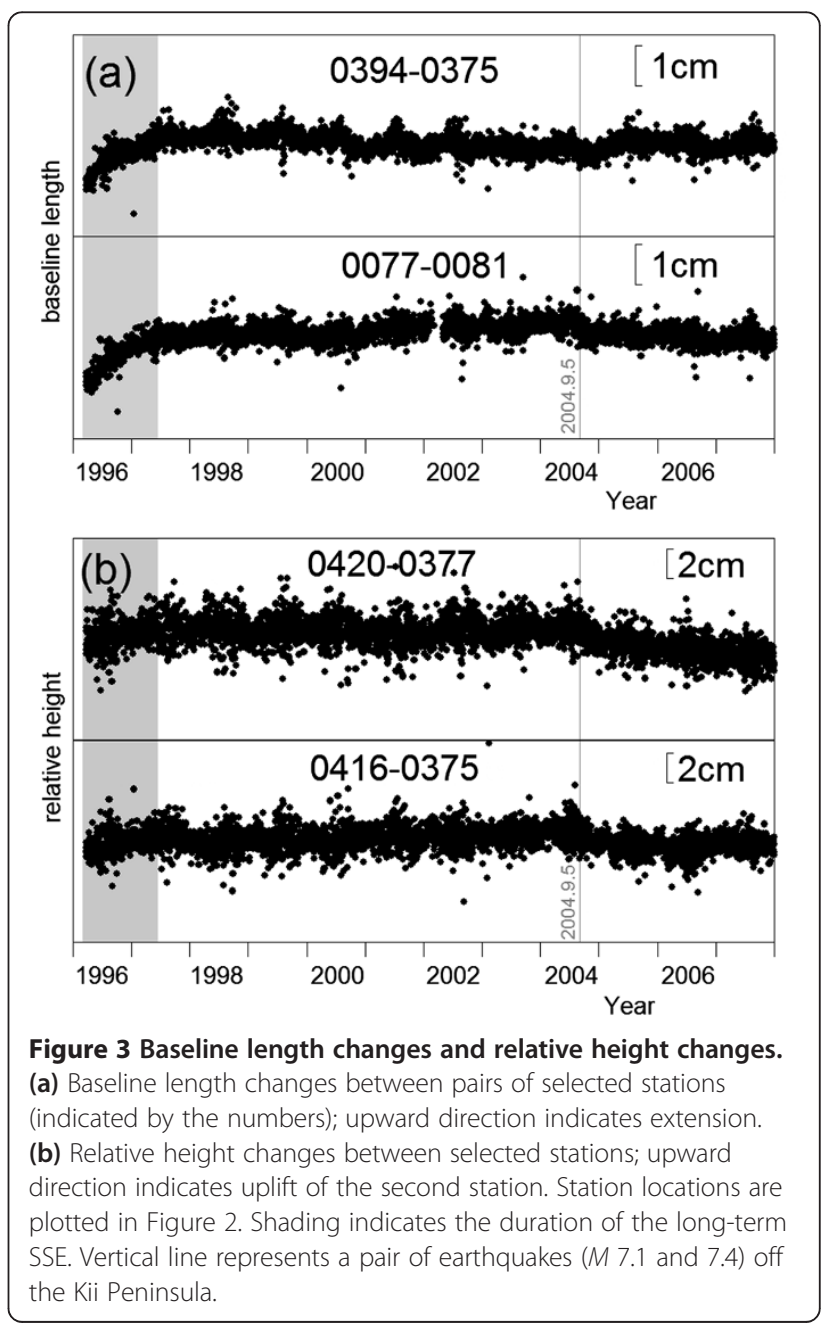


whole network is divided into three subnetworks that have a common station in Tsukuba whose coordinates are strongly constrained to values derived from $a$ priori coordinates and velocity. This station has an anomalous annual component due to groundwater-induced vertical movements (Munekane et al. 2004); therefore, the coordinates of the F2 solution include annual variation. These error factors can be reduced by measuring displacements over short baselines. The daily coordinates of the F2 solution were analyzed up to July 1996. In Figure 4, we combined the adjusted baseline data of the F3 data by using the period of overlap from March to July 1996 to match a trend in the two records. The baseline length change rate was almost constant from October 1994 through 1995, and unsteady change seemed to start in early 1996. The duration of the unsteady change was 1 to 1.5 years in length.

\section{Estimation of the slip distribution}

The unsteady horizontal displacement around the Kii Channel from 1996 to 1997 was as small as $1 \mathrm{~cm}$. This small displacement can be seen across multiple stations and is thus unlikely to have been due to local phenomena specific to each station. We assumed that the unsteady displacement was caused by a long-term SSE. We estimated the slip vector on the plate interface by the inversion technique (Yabuki and Matsu'ura 1992) with some modifications (Naito and Yoshikawa 1999; Yamamoto 2005) using the point source formulation of Okada (1992). The method of Yabuki and Matsu'ura (1992) represents the slip distribution and fault configuration with the superposition of B spline functions. We estimated slip vectors using boxcar functions with a smoothness constraint for regularization. The smoothness was determined so as to minimize Akaike's Bayesian Information Criterion (ABIC, Akaike 1980). The unsteady displacement appears to have started from the beginning of 1996, but we used the horizontal displacements starting from March 1996 for the inversion (Figure 5). We used a $17 \times 21$ grid of point sources on the plate interface and the plate interface configuration of Hirose et al. (2008) to calculate the slip

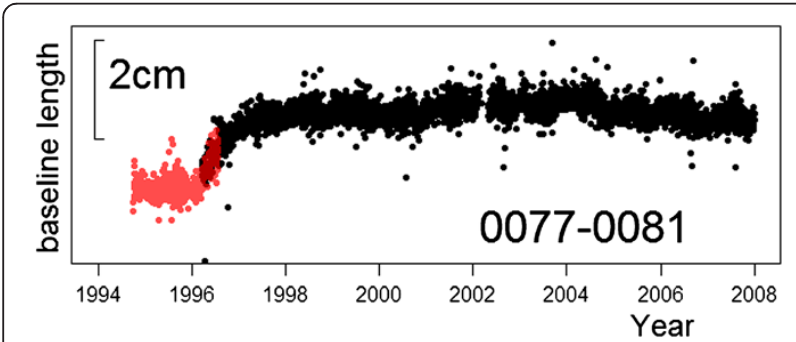

Figure 4 Baseline length change between stations 0077 and 0081 (locations in Figure 2). Upward direction indicates extension. Red dots denote daily coordinate of the F2 solution.

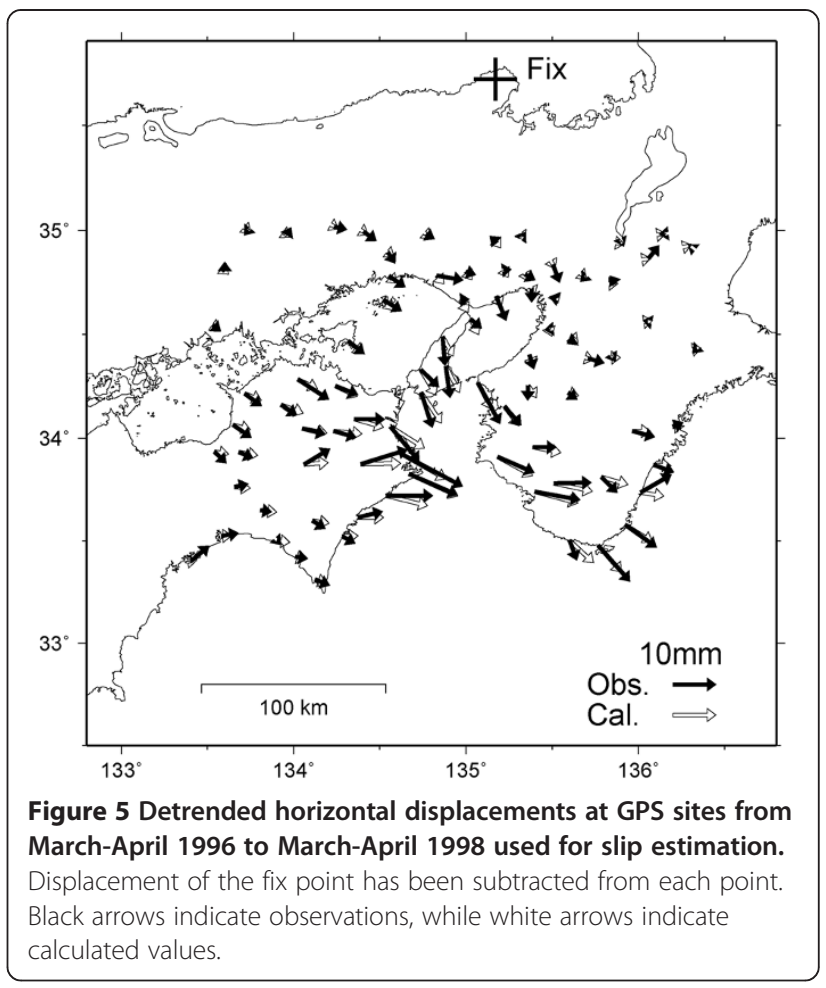

vectors (Figure 6). The grid interval of the north-south direction was about $11 \mathrm{~km}$, and that of the east-west direction was about $9 \mathrm{~km}$. We set the slip to zero at the outside of the grids. Dip and strike angles were derived from the plate configuration using continuous curvature splines in tension (Smith and Wessel 1990).

\section{Results and discussion}

Slip distribution of the long-term slow slip

We found unsteady horizontal displacement around the Kii Channel from 1996 to 1997. Estimated slip distribution that caused the displacement is shown in Figure 6. The slip beneath the Kii Channel showed a southeastward motion. For the Bungo Channel and the Tokai area along the Nankai Trough, the slip area of long-term SSEs was located on the updip side of the deep lowfrequency tremor source region (Obara 2011). Deep low-frequency tremors have also been observed on the downdip side of long-term SSEs at subduction zones in Alaska (Peterson and Christensen 2009) and Mexico (Kostoglodov et al. 2010). Activation of the low-frequency tremors has been reported in association with the occurrence of the long-term SSEs (Hirose and Obara 2005; Kobayashi et al. 2006). Low-frequency tremors along the Nankai Trough are distributed in a belt-like zone at depths of about $30 \mathrm{~km}$ on the plate interface, and a distinct gap occurs in the Kii Channel (Obara 2009). The center of our estimated distribution of slip on the plate interface in the Kii Channel (Figure 6) is at depths of 20 to 

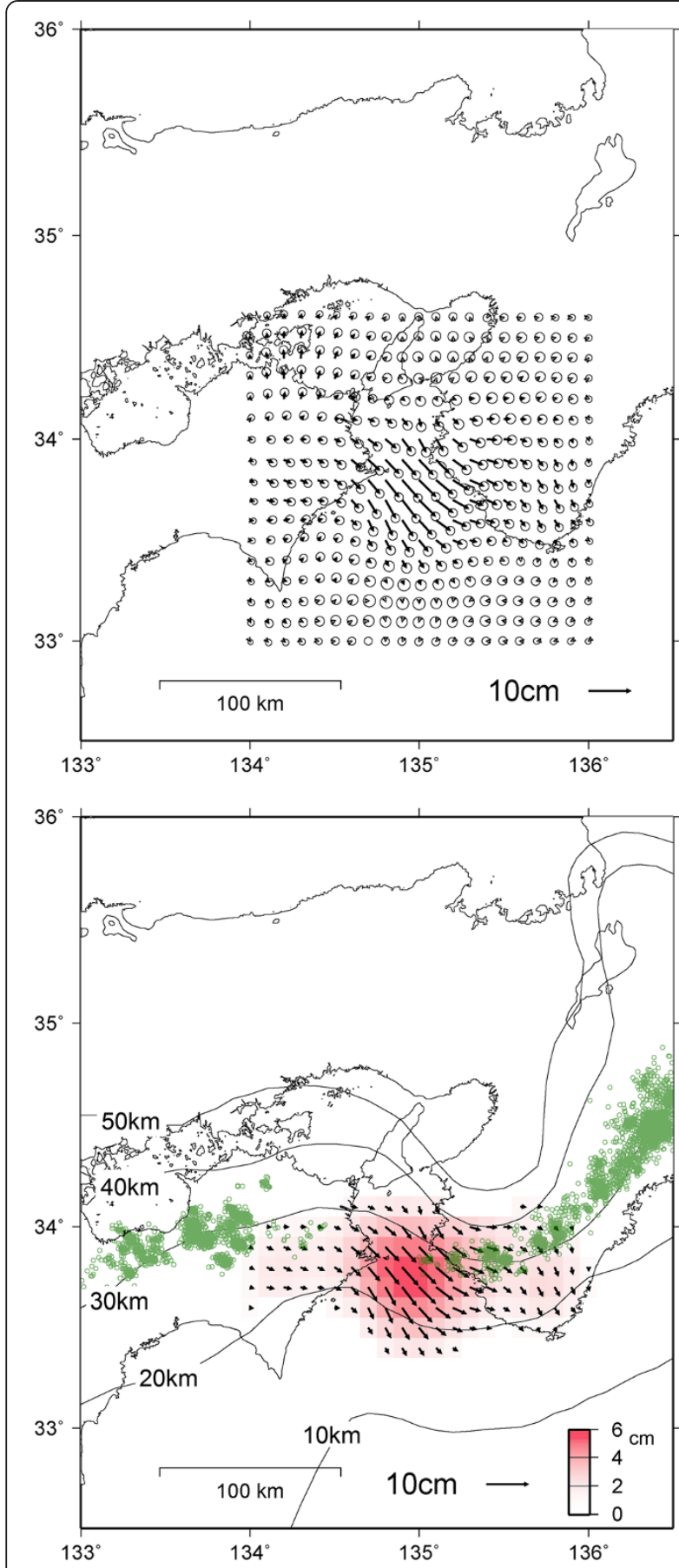

Figure 6 Estimated slip distribution from March-April 1996 to March-April 1998. Slip arrows indicate the motion of the overriding plate against the subducting Philippine Sea plate. Small circles at the tips of arrows in the upper figure indicate the estimation errors. Slip arrows in the lower figure were selected when sizes were greater than the errors, and slip directions ranged between east and south. Green circles indicate the epicenters of low-frequency earthquakes from January 2006 to December 2010. Thin black contours show the depths of the upper boundary of the Philippine Sea slab (Hirose et al. 2008).
$30 \mathrm{~km}$. This is consistent with the spatial relationship of long-term SSEs and deep low-frequency tremors previously reported. However, the slip distribution in the Kii Channel is adjacent to a gap in the deep lowfrequency tremor episodes along the Nankai Trough. This gap is considered to reflect a genuine absence of detectable tremors, rather than a gap in observation points (Obara and Hirose 2005). Nishimura et al. (2013) estimated short-term SSEs along the Nankai Trough using GPS data. They found no definite short-term SSEs in the Kii Channel. Our data indicate that long-term SSEs may also occur adjacent to the inactive region of lowfrequency tremors.

Although we used GPS data starting from March 1996 for our estimation, the long-term SSE seems to have started slightly earlier (Figure 4). Therefore, the total slip must be larger than our estimate. The ratio between the change from January 1996 and the change from March 1996 is 1.15 times from Figure 4. This ratio represents a value in a baseline length, but we assumed that it is applicable to the whole slip. We selected slips whose sizes were greater than the errors, and slip directions ranged between east and south (Figure 6). Applying a factor of 1.15 times, the energy released in the long-term SSE from 1996 would be equivalent to an earthquake of $M w$ 6.7 assuming a rigidity of $40 \mathrm{GPa}$. Estimated moment magnitudes of the long-term SSEs along the Nankai Trough are $M w 7.1$ for the Tokai region (Suito and Ozawa 2009), $M w 7.0$ to 7.1 (Ozawa et al. 2013) for the Bungo Channel, $M w 6.7$ to 6.8 (Yarai and Ozawa 2013) for the Hyuga-nada, and $M w 6.5$ (Kobayashi 2010) for western Shikoku. The moment magnitude of the longterm SSE in the Kii Channel estimated here is smaller than that of the Tokai and the Bungo Channel, and is comparable to that of the Hyuga-nada.

\section{Along-strike variation of the long-term slow slip events}

Along the Nankai Trough, long-term SSEs have been observed in some segments as mentioned above. Mitsui and Hirahara (2006) compiled the features of globally detected long-term SSEs and pointed out that the slab dip and its lateral change are important factors for controlling their occurrences. Schmidt and Gao (2010) analyzed SSEs on the Cascadia subduction zone from 1998 to 2008 and reported that the area of the greatest cumulative slip correlates with the along-strike bend of the subduction zone. Kii Channel is located on the along-strike bend of the isodepth contours of the Philippine Sea plate (Hirose et al. 2008) (Figure 6). These reports are consistent with the fact that a long-term SSE has occurred in the Kii Channel.

Long-term SSEs before GPS deployment have been investigated using other geodetic methods along the Nankai Trough. Figure 7 shows the spatiotemporal distribution of these long-term SSEs. In the Tokai region, two long-term 


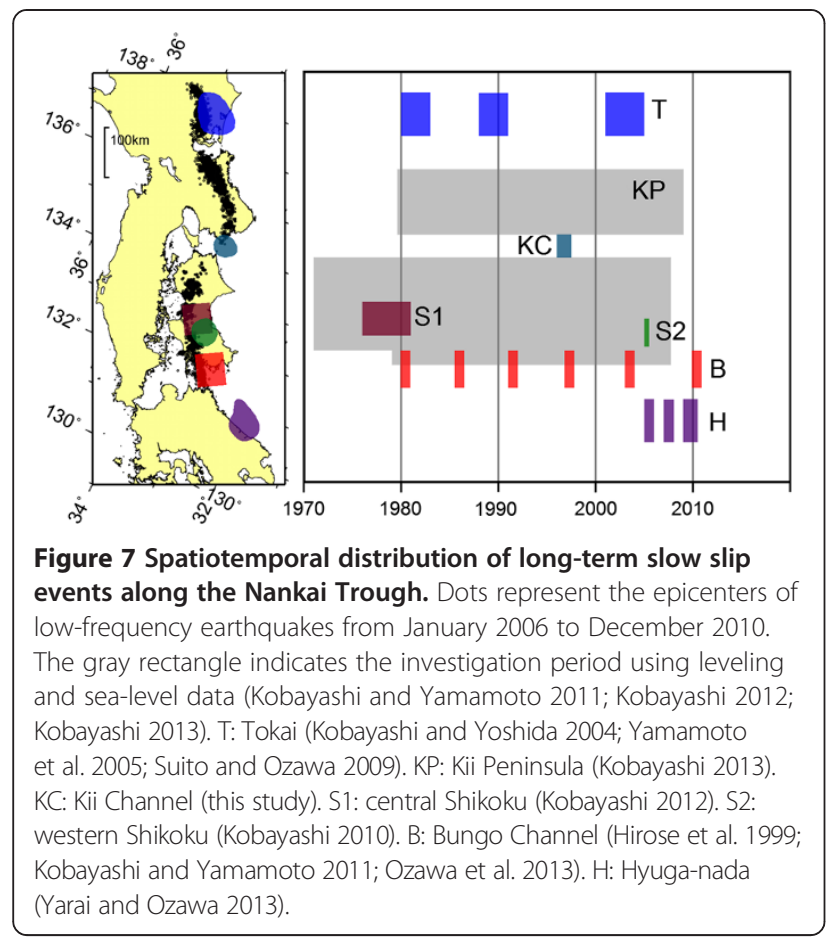

SSEs during the periods of 1980 to 1982 and 1988 to 1990 have been reported using sea-level data (Kobayashi and Yoshida 2004). Yamamoto et al. (2005) reported a longterm SSE of 1988 to 1990 using tilt data. The timing of the event estimated from the different types of data is consistent. In the Bungo Channel, Kobayashi and Yamamoto (2011) reported three long-term SSEs using leveling and sea-level data for the period from 1979 to 1991. The recurrence time of the SSEs is rather stable and is about 5 to 6 years. In central Shikoku, Kobayashi (2012) reported a long-term SSE around 1978 to 1980 using leveling and sea-level data. Such an event has not been observed by GPS since 1996 in this area. In the Kii Peninsula, a longterm SSE has not yet been observed by GPS and leveling data since 1980 (Kobayashi 2013). Thus, the characteristics of long-term SSEs are different along the strike of the Nankai Trough.

Along the Nankai Trough, the maximum slip-deficit rate is estimated off Shikoku (Ito and Hashimoto 2004; Yoshioka and Matsuoka 2013). Epicenters of the 1944 Tonankai earthquake and the 1946 Nankai earthquake are located off the coast of the Kii Peninsula (Figure 1) where the slip-deficit rate is relatively low. A long-term SSE has not yet been observed in the southern Kii Peninsula close to these epicenters. Hirose et al. (2009) numerically simulated earthquakes and long-term SSEs along the Nankai Trough using a three-dimensional earthquake cycle model. They pointed out the possibility that one of the long-term SSEs is accelerated and leads to an earthquake. Along the Nankai Trough, including the southern Kii Peninsula, it is necessary to store information about the history of longterm SSEs for the prediction of large earthquakes.

\section{Conclusions}

In this paper, we have reported on a long-term slow slip event that occurred from 1996 to 1997 in the Kii Channel along the Nankai Trough in southwestern Japan. Unsteady eastward or southeastward displacements were seen around the Kii Channel using detrended GPS daily coordinate data. The duration of the event was 1 to 1.5 years in length. The estimated magnitude of the event was equivalent to $M w 6.7$. The moment magnitude of the event was smaller than those of Tokai and the Bungo Channel along the Nankai Trough. The slip was located slightly shallower in comparison with the depth of the low-frequency earthquakes around the Kii Channel. The characteristics of long-term slow slip events are different along the strike of the Nankai Trough. More information about the history of long-term slow slip events would be valuable for improving our understanding of plate boundary characteristics and the prediction of large earthquakes.

\section{Competing interests}

The author declares that he has no competing interests.

\section{Acknowledgements}

The GPS F3 coordinate data and offset data were provided by the Geospatial Information Authority of Japan. We thank Dr. Hatanaka for providing the GPS conformed F2 coordinate data. We thank the reviewers for their careful and constructive reviews. We used MICAP-G software (Naito and Yoshikawa 1999; Yamamoto 2005) based on the formulation of Okada (1992) for estimating slip distribution and GMT software (Wessel and Smith 1998) for drafting figures.

Received: 30 September 2013 Accepted: 12 February 2014 Published: 9 April 2014

\section{References}

Akaike H (1980) Likelihood and the Bayes procedure. In: Bernard JM, DeGroot MH, Lindley DV, Smith AFM (ed) Bayesian statistics. University Press, Valencia, Spain, pp 143-166

Douglas A, Beavan J, Wallace L, Townend J (2005) Slow slip on the northern Hikurangi subduction interface, New Zealand. Geophys Res Lett 32, L16305. doi:10.1029/2005GL023607

Dragert H, Wang K, James TS (2001) A silent slip event on the deeper Cascadia subduction interface. Science 292:1525-1528

Freymueller J, Hreinsdöttir S, Zweck S, Haeussler PJ (2002) The 1998-2002 deep megathrust slip event, Alaska. Eos Trans Amer Geophys Union 83(47):G61A-G0972A

Hatanaka Y, lizuka T, Sawada M, Yamagiwa A, Kikuta Y, Johnson JM, Rocken C (2003) Improvement of the analysis strategy of GEONET. Bull Geogr Surv Inst 49:11-37

Hatanaka Y, Iwashita C, Nogami K, Kotani K (2004) Re-analysis of continuous GPS network before GEONET. Tech Rep Geogr Surv Inst Japan A4-3:123-126 [in Japanese]

Hirose H, Obara K (2005) Repeating short- and long-term slow slip events with deep tremor activity around the Bungo channel region, southwest Japan. Earth Planets Space 57:961-972

Hirose H, Hirahara K, Kimata F, Fujii N, Miyazaki S (1999) A slow thrust slip event following the two 1996 Hyuganada earthquakes beneath the Bungo Channel, southwest Japan. Geophys Res Lett 26:3237-3240

Hirose F, Nakajima J, Hasegawa A (2008) Three-dimensional seismic velocity structure and configuration of the Philippine Sea slab in southwestern Japan estimated by double-difference tomography. J Geophys Res 113, B09315. doi:10.1029/2007JB005274 
Hirose F, Maeda K, Takayama H (2009) An attempt at simulation of long term slow slip events and seismic cycle in the Tokai region. J Seismol Soc Jpn 62:67-84 [in Japanese with English abstract]

Hirose H, Asano Y, Obara K, Kimura T, Matsuzawa T, Tanaka S, Maeda T (2010) Slow earthquakes linked along dip in the Nankai subduction zone. Science 330:1502

Ito T, Hashimoto M (2004) Spatiotemporal distribution of interplate coupling in southwest Japan from inversion of geodetic data. J Geophys Res 109, B02315. doi:10.1029/2002JB002358

Katsumata A, Kamaya N (2003) Low-frequency continuous tremor around the Moho discontinuity away from volcanoes in the southwest Japan. Geophys Res Lett 30:1020. doi:10.1029/2002GL0159812

Kobayashi A (2010) A small scale long-term slow slip occurred in the western Shikoku in 2005. J Seismol Soc Jpn 63:97-100 [in Japanese with English abstract]

Kobayashi A (2012) Long-term slow slip event around Kochi City from 1977 to 1980. J Seismol Soc Jpn 64:63-73 [in Japanese with English abstract]

Kobayashi A (2013) Vertical crustal deformation in the Kii Peninsula deduced from leveling and sea level data, 1972-2009. J Seismol Soc Jpn 66:15-25 [in Japanese with English abstract]

Kobayashi A, Yamamoto T (2011) Repetitive long-term slow slip events beneath the Bungo Channel, southwestern Japan, identified from leveling and sea level data from 1979 to 2008. J Geophys Res 116, B04406. doi:10.1029/ 2010JB007822

Kobayashi A, Yoshida A (2004) Recurrence of the Tokai slow slip inferred from the tide gauge data at Maisaka. J Geod Soc Jpn 50:209-212 [in Japanese with English abstract]

Kobayashi A, Yamamoto T, Nakamura K, Kimura K (2006) Short-term slow slip events detected by the strainmeters in Tokai region in the period from 1984 to 2005. J Seismol Soc Jpn 59:19-27 [in Japanese with English abstract]

Kostoglodov V, Husker A, Shapiro NM, Payero JS, Campillo M, Cotte N, Clayton R (2010) The 2006 slow slip event and nonvolcanic tremor in the Mexican subduction zone. Geophys Res Lett 37, L24301. doi:10.1029/2010GL045424

Lowry AR, Larson KM, Kostoglodov V, Bilham R (2001) Transient fault slip in Guerrero, southern Mexico. Geophys Res Lett 28:3753-3756

Mao A, Harrison CGA, Dixon TH (1999) Noise in GPS coordinate time series. J Geophys Res 104:2797-2816. doi:10.1029/1998JB900033

Mitsui N, Hirahara K (2006) Slow slip events controlled by the slab dip and its lateral change along a trench, Earth Planet. Sci Lett 245:344-358

Miyazaki S, Saito T, Sasaki M, Hatanaka Y, limura Y (1997) Expansion of GSI's nationwide GPS array. Bull Geogr Surv Inst 43:23-34

Munekane H, Tobita M, Takashima K (2004) Groundwater-induced vertical movements observed in Tsukuba. Japan Geophys Res Lett 31, L12608. doi:10.1029/2004GL020158

Murakami M, Ozawa S (2004) Mapped vertical deformation field of Japan derived from continuous GPS measurements and its tectonic implications. J Seismol Soc Jpn 57:209-231 [in Japanese with English abstract]

Naito H, Yoshikawa S (1999) A program to assist crustal deformation analysis. J Seismol Soc Jpn 52:101-103 [in Japanese]

Nakagawa H, Toyofuku T, Kotani K, Miyahara B, Iwashita C, Kawamoto S, Hatanaka Y, Munekane H, Ishimoto M, Yutsudo T, Ishikura N, Sugawara Y (2009) Development and validation of GEONET New Analysis Strategy (version 4). J Geogr Surv Inst 118:1-8 [in Japanese]

Nakano T, Hirahara K (1997) GPS observations of postseismic deformation for the 1995 Hyogo-ken Nanbu earthquake. Japan Geophys Res Lett 24:503-506

Nishimura T, Matsuzawa T, Obara K (2013) Detection of short-term slow slip events along the Nankai Trough, southwest Japan, using GNSS data. J Geophys Res 118:1-14. doi:10.1002/jgrb.50222

Obara K (2009) Inhomogeneous distribution of deep slow earthquake activity along the strike of the subducting Philippine Sea plate. Gondowana Res 16:512-526

Obara K (2011) Characteristics and interactions between non-volcanic tremor and related slow earthquakes in the Nankai subduction zone, southwest Japan. J Geodyn 52:229-248. doi:10.1016/j.jog.2011.04.002

Obara K, Hirose H (2005) Non-volcanic deep low-frequency tremors accompanying slow slips in the southwest Japan subduction zone. Tectonophysics 417:33-51

Obara K, Hirose H, Yamamizu F, Kasahara K (2004) Episodic slow slip events accompanied by non-volcanic tremors in southwest Japan subduction zone. Geophys Res Lett 31, L23602. doi:10.1029/2004GL020848

Okada Y (1992) Internal deformation due to shear and tensile faults in a half-space. Bull Seism Soc Am 82(2):1018-1040
Ozawa S, Murakami M, Kaidzu M, Tada T, Sagiya T, Hatanaka Y, Yarai H, Nishimura $\mathrm{T}$ (2002) Detection and monitoring of ongoing aseismic slip in the Tokai region, central Japan. Science 298:1009-1012

Ozawa S, Nishimura T, Suito H, Kobayashi T, Tobita M, Imakiire T (2011) Coseismic and postseismic slip of the 2011 magnitude-9 Tohoku-Oki earthquake. Nature 475:373-376. doi:10.1038/nature10227

Ozawa S, Yarai H, Imakiire T, Tobita M (2013) Spatial and temporal evolution of the long-term slow slip in the Bungo Channel, Japan. Earth Planets Space 65:67-73

Peterson CL, Christensen DH (2009) Possible relationship between nonvolcanic tremor and the 1998-2001 slow slip event, south central Alaska. J Geophys Res 114, B06302. doi:10.1029/2008JB006096

Protti M, Gonzales V, Kato T, linuma T, Miyasaki S, Obana K, Kaneda Y, LaFemina P, Dixon T, Schwartz S (2004) A creep event on the shallow interface of the Nicoya Peninsula, Costa Rica seismogenic zone. Eos Trans Amer Geophys Union 85(47):S441D-07

Rogers G, Dragert H (2003) Episodic tremor and slip on the Cascadia subduction zone: the chatter of silent slip. Science 300:1942-1943

Sagiya T (2004) A decade of GEONET: 1994-2003-the continuous GPS observation in Japan and its impact on earthquake studies. Earth Planets space 56:xxix-xli

Schmidt DA, Gao H (2010) Source parameters and time-dependent slip distributions of slow slip events on the Cascadia subduction zone from 1998 to 2008. J Geophys Res 115:B00A18. doi:10.1029/2008JB006045

Schwartz SY, Rokosky JM (2007) Slow slip events and seismic tremor at circum-Pacific subduction zones. Rev Geophys 45, RG3004. doi:10.1029/ 2006RG000208

Smith WHF, Wessel P (1990) Gridding with continuous curvature splines in tension. Geophysics 55:293-305

Suito H, Ozawa S (2009) Transient crustal deformation in the Tokai district. J Seismol Soc Jpn 61:113-135 [in Japanese with English abstract]

Wessel P, Smith WHF (1998) New, improved version of the Generic Mapping Tools released. EOS Trans Amer Geophys Union 79:579

Yabuki T, Matsu'ura M (1992) Geodetic data inversion using a Bayesian information criterion for spatial distribution of fault slip. Geophys J Int 109:363-375

Yamamoto T (2005) Development of a software to assist crustal deformation analysis. Tech Rep Meteorological Res Inst 46:156-159 [in Japanese]

Yamamoto E, Matsumura S, Ohkubo T (2005) A slow slip event in the Tokai area detected by tilt and seismic observation and its possible recurrence. Earth Planets Space 57:917-923

Yarai H, Ozawa S (2013) Quasi-periodic slow slip events in the afterslip area of the 1996 Hyuga-nada earthquakes. Japan J Geophys Res 118:2512-2527. doi:10.1002/jgrb.50161

Yoshioka S, Matsuoka Y (2013) Interplate coupling along the Nankai Trough, southwest Japan, inferred from inversion analyses of GPS data: effects of subducting plate geometry and spacing of hypothetical ocean-bottom GPS stations. Tectonophysics 600:165-174

doi:10.1186/1880-5981-66-9

Cite this article as: Kobayashi: A long-term slow slip event from 1996 to 1997 in the Kii Channel, Japan. Earth, Planets and Space 2014 66:9.

\section{Submit your manuscript to a SpringerOpen ${ }^{\odot}$ journal and benefit from:}

- Convenient online submission

- Rigorous peer review

- Immediate publication on acceptance

- Open access: articles freely available online

- High visibility within the field

- Retaining the copyright to your article

Submit your next manuscript at $>$ springeropen.com 